\title{
MECHANICAL AND ABRASIVE WEAR PROPERTIES OF FRICTION STIR WELDED JOINTS OF ALUMINUM ALLOY AA6061-T6 WITH/WITHOUT NICKEL COATING
}

\author{
BAHUGUNA Shailja ${ }^{1}$, ARYA Pradyumn K², PATEL Vinay Kumar ${ }^{1 *}$ \\ ${ }^{I}$ Department of Mechanical Engineering, Govind Ballabh Pant Institute of Engineering and Technology, Pauri- \\ Garhwal 246001, Uttarakhand, India, e-mail:vinaykrpatel@gmail.com \\ ${ }^{2}$ Department of Mechanical Engineering, Indian Institute of Technology Indore 452020, Madhya Pradesh, India
}

\begin{abstract}
The purpose of this work is to examine the microstructure, mechanical and sand abrasive properties of friction stir welded joints of aluminium alloy AA6061-T6 with and without nickel coating. A total eighteen samples, six samples of AA6061-T6 plates, six samples of $10 \mu \mathrm{m}$ thick Ni coated AA6061-T6 plates and six samples of $15 \mu \mathrm{m}$ thick Ni coated AA6061-T6 plates were friction stir welded by using different tool rotation speed $(710 \mathrm{rpm}, 1000 \mathrm{rpm}, 1400 \mathrm{rpm})$ and different welding speed $(28 \mathrm{~mm} / \mathrm{min}, 56 \mathrm{~mm} / \mathrm{min})$. The joints manufactured using $1400 \mathrm{rpm}$ tool rotation speed and $56 \mathrm{~mm} / \mathrm{min}$ welding speed generated the highest tensile strength and percent elongation with joint efficiency of 69.05\% with $15 \mu \mathrm{m}$ Ni-coated AA6061-T6 plates and joints manufactured from $10 \mu \mathrm{m} \mathrm{Ni-coated} \mathrm{AA6061-T6} \mathrm{plates} \mathrm{using} 1000 \mathrm{rpm}$ tool rotation speed and 28 $\mathrm{mm} / \mathrm{min}$ welding speed generated the highest impact energy and higher hardness in NZ compared to the other joints. The $15 \mu \mathrm{m}$ Ni-coated AA6061-T6 plates exhibited better abrasive wear resistant properties than the 1015 $\mu \mathrm{m}$ Ni-coated plates. Microstructure investigation showed the precipitate size variations and their distributions and after friction stir welding, these precipitates became slightly coarser in the HAZ but finer in the nugget region.
\end{abstract}

KEYWORDS: Friction stir welding, Nickel coating, Aluminium alloy, Mechanical Properties, Wear properties

\section{Introduction}

The necessity for greater fuel efficiency in automotive and aerospace sector have motivated the increased use of aluminium alloys and aluminium foam for lightweight designs in recent years [1-3]. Due to good strength to weight ratio, higher malleability and good corrosion resistance, aluminium Alloy 6061-T6 is widely used in construction and automobile industries. For improving the corrosion resistance and strength of Al alloy 6061-T6, nickel coating is required and joining of $\mathrm{Al}$ alloy is gradually being increased in structural designing and manufacturing industries. There is numerous welding process for joining Al Alloy, most of which are described publicly accessible on reference [4]. For application purpose, gas metal and gas tungsten arc welding processes are the most commonly used fusion welding techniques for aluminium and its alloys [5]. The main fusion welding problems with aluminium and its alloys are weld metal porosity, lack of fusion, hot cracking and reduction of mechanical properties $[6,7]$. friction stir welding (FSW) is an autogenously new solid-state welding process for particularly welding of aluminium and its alloys invented in TWI [8-10]. An abundant number of welding techniques have been suggested so far to deal with different types of materials however, the welding of dissimilar materials stills remains a challenge [9].

For joining dissimilar materials, FSW has been widely implemented and often performed on a number of joint configurations including butt joints, lap joints and $\mathrm{T}$ joints etc [11]. FSW is an autogenous solid-state welding process in which the friction between the nonconsumable rotating tool and the work-piece generates heat and the high force under the tool 
induces a plasticized region of material to shape around the probe $[12,13]$. There are two sides in FSW, one is advancing side (AS) and another is retreating side (RS) and material is combined more intensely on the advancing side than material on the retreating side [14]. FSW method uses a non-consumable cylindrical tool consisting of a shoulder and pin, and the FSW performance depends on welding tool design [15]. During the welding procedure, the welding zone in FSW is totally separated from the environment [16].

Kumar and Patel [17] studied the mechanical, microstructural and abrasive wear properties of AA6061-T6 aluminium alloy by inter-plate reinforcing of the silicon carbide microparticles $(\mu \mathrm{SiC})$ and silicon nitride microparticles $\left(\mu \mathrm{Si}_{3} \mathrm{~N}_{4}\right)$ and demonstrated that the reinforcement of $\mu \mathrm{SiC}$ and $\mu \mathrm{Si}_{3} \mathrm{~N}_{4}$ decreased the tensile properties of the welded joint but improved the abrasive wear and microhardness properties considerably in the stir zone (SZ). Cavaliere et al. [18] investigated the effect of welding parameters on FSW-produced mechanical and microstructural properties of the AA6082 joints. Results showed that the ductility and tensile strength of the FSW joints were exhibited of the highest magnitude at low welding speed (40 and $56 \mathrm{~mm} / \mathrm{min})$ and high welding speed $(80 \mathrm{~mm} / \mathrm{min})$ respectively. The nugget microstructure was observed to be finer and more uniform and a significant variability was observed in the mean grain size. Xu et al. [19] observed the evolution of temperature, microstructural, and mechanical properties of FSW thick 2219-O Alloy joints. In the nugget region, the microstructure was extremely fine and equiaxed grains; the grain size at the top of the weld was significantly coarser than at the bottom of the weld. The TMAZ grains were elongated, and coarsened in the HAZ. With increased tool rotational speed (TRS) and decreased percentage elongation, the yield strength and tensile force of joints increased. Rodrigues et al. [20] found that a larger nugget grain size was displayed on the conical neck, and a smaller grain size was displayed in the welds. The weld produced with the conical shoulder showed a reduction of $30 \%$ in elongation with even matching hardness condition and with scrolled shoulder, it showed a reduction of $70 \%$ in elongation, a reduction of $15 \%$ in hardness than base metal. Cavaliere et al. [21] clearly demonstrated that the ductility of the materials reached the highest magnitude for welding speed of 40 and $56 \mathrm{~mm} / \mathrm{min}$ and the lowest rotation speed of $500 \mathrm{rpm}$ which decreased sharply as the welding and rotational speed of the tool increased. Sharma et al. [22] found that the friction stir micrographs of welded joints displayed onion ring and zigzag line in weld nugget, and the nugget zone microstructure showed fine and equiaxed grain. The mechanical properties were found to increase with decreasing the welding speed i.e. at high heat input per unit length. Fujii et al. [23] analysed the mechanical properties and microstructure of the AA1050-H24, AA5083-O and AA6061T6 FSW with three different probes of column without threads, threaded columns and triangular prisms. The triangular prism tool was better suited for high speed at middle rotation speed, the column with threads was better suited at middle rotation speed and the shape of the tool did not affect the mechanical and microstructural properties of the joints at low rotation speed. Scialpi et al. [24] tested the friction stir welded AA6082-T6's microstructures and mechanical properties with three separate machine shoulder instruments with scroll and fillet, cavity and fillet, and just filet. The combination of fillet and cavity was recognized the best device in all three different shoulder configurations as it improved the joint's longitudinal and traverse strength and provided the best crown surface. The tensile strength of FSW AA6061 aluminium alloy joints was evaluated by Elangovan et al. [25] using a mathematical model written in $\mathrm{C}$ software with five separate device pin profile. Compared to other joints, the joints developed by the square pin profile tool with a TRS of $1200 \mathrm{rpm}$, welding speed of $1.25 \mathrm{~mm} / \mathrm{s}$ and axial force of $7 \mathrm{KN}$ exhibited superior tensile properties. Kumar et al. [26] found that the recrystallized grain size in the weld nugget was increased with increasing axial load and transforming the elongated grain structure of the base material into small recrystallized equiaxed grains. Dehghani [27] investigated the microstructural and mechanical properties of 
FSW AA7075-O plate with the tool pin used as H13 tool steel coated with a nitride wear resistance film. Within the nugget region, the microstructure was extremely fine and equiaxed grains, while in the HAZ, it was coarser. The sum of nugget zone specimen displaced in the bending test was much smaller than that of base metal.

According to the study of various literature reviews it is observed that no work is found on the investigation of joint properties of FSW of nickel coated aluminium alloy. The present work aims to evaluate the effect of the tool rotation speed and the welding speed on mechanical and microstructural behaviour of AA6061-T6 plate without nickel coating, and with nickel coating of $10 \mu \mathrm{m}$ and $15 \mu \mathrm{m}$ thickness.

\section{Experimental procedure}

The base material applied in the present investigation was $5 \mathrm{~mm}$ thick aluminium alloy AA6061-T6 (procured from Bharat Aerospace Metals, Mumbai) with precipitation hardened containing magnesium and silicon as its major parts. The chemical composition and mechanical properties of AA6061 Al alloy are listed in Tables 1 and 2 respectively.

Table 1: Chemical composition of AA6061

\begin{tabular}{cccccccr}
\hline Alloy & $\mathrm{Mg}$ & $\mathrm{Si}$ & $\mathrm{Mn}$ & $\mathrm{Fe}$ & $\mathrm{Zn}$ & $\mathrm{Ti}$ & $\mathrm{Al}$ \\
\hline AA6061 & 0.92 & 0.61 & 0.06 & 0.33 & 0.03 & 0.02 & $\mathrm{Bal} .$. \\
\hline \multicolumn{1}{c}{ Table 2: Mechanical } & properties of AA6061 \\
\hline Base Material & UTS (MPa) & \% Elongation & Microhardness (HV) \\
\hline AA6061 & \multicolumn{2}{c}{308} & \multicolumn{2}{c}{12} & \multicolumn{2}{c}{106} \\
\hline
\end{tabular}

Aluminium alloy plate AA6061 having a size of $100 \mathrm{~mm} \times 50 \mathrm{~mm} \times 5 \mathrm{~mm}$ was used in the present work without and with nickel coating of thickness $10 \mu \mathrm{m}$ and $15 \mu \mathrm{m}$. Such nickel coating on aluminium alloys plate results in a substantial enhancement in the material's corrosion resistance.

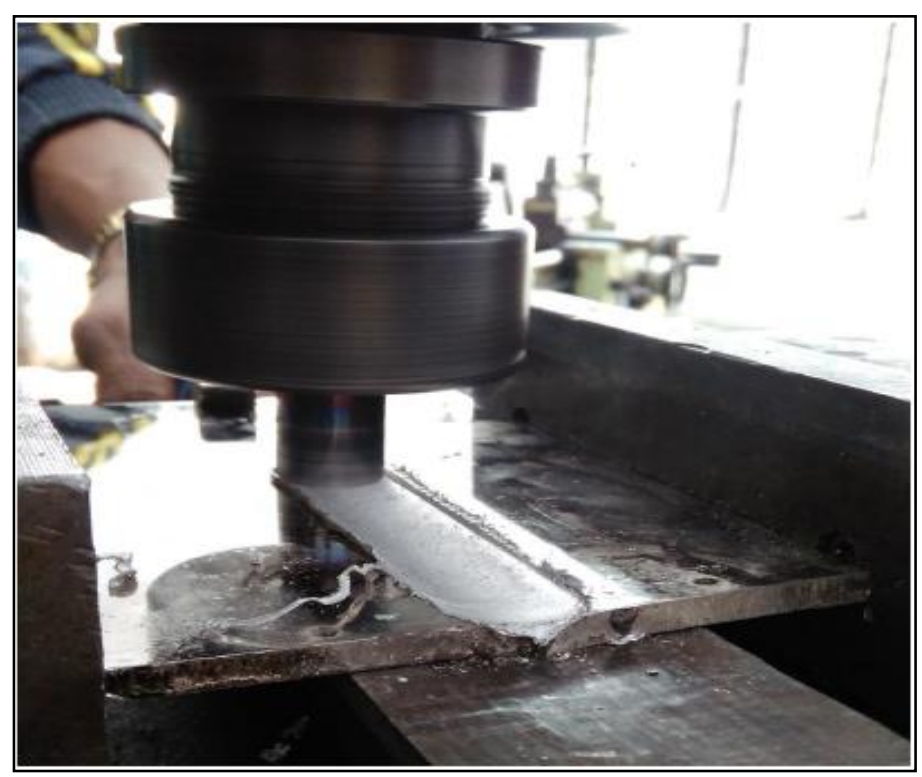

Fig.1 FSW setup on milling machine and operation

The aluminium alloys 6061 plates were cleaned by the steel brush and acetone before the weld initiated. The machine used for FSW was a traditional vertical milling machine that was reworked into a FSW by employing a FSW setup. The adjoining plates to be welded were gripped within the fixture, and FSW tool was fastened within the collect mounted within the 
head of vertical milling machine. After fixing the FSW tool and plates, machine was powered to take different combination of designated tool rotation speed and traverse speed. The image of fixture set up and welding operation on the work-piece is shown in the Figure 1. FSW tool was prepared from a H13 tool steel rod via simple turning operation on the lathe machine. The FSW tool was a concave shoulder square pin tool having no threads on its periphery and the pin length was chosen slightly smaller than the plate thickness.

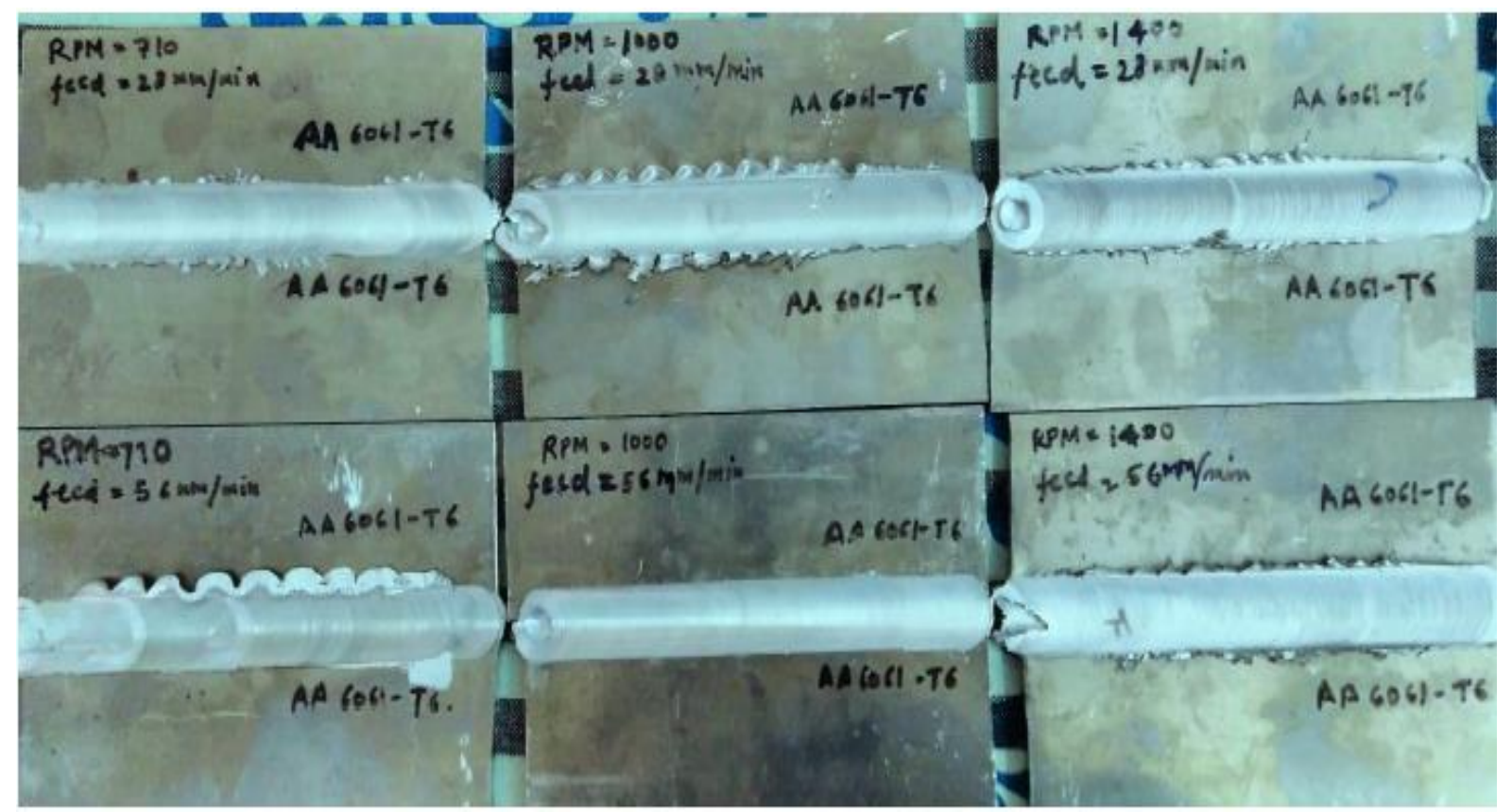

Fig. 2a FSW of AA6061 plate

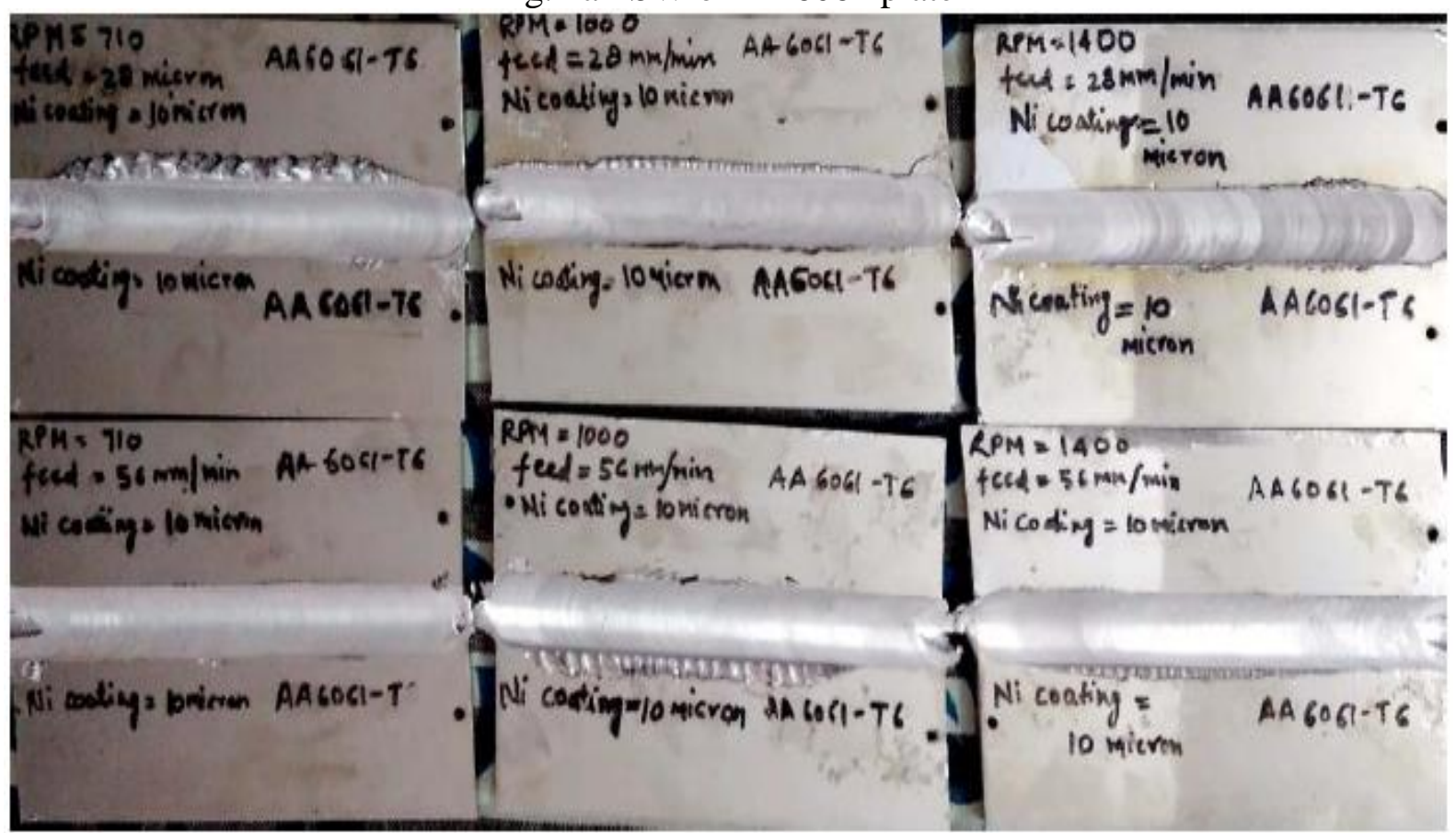

Fig. 2b FSW of 10-micron thickness Ni coated AA6061-T6 plates 


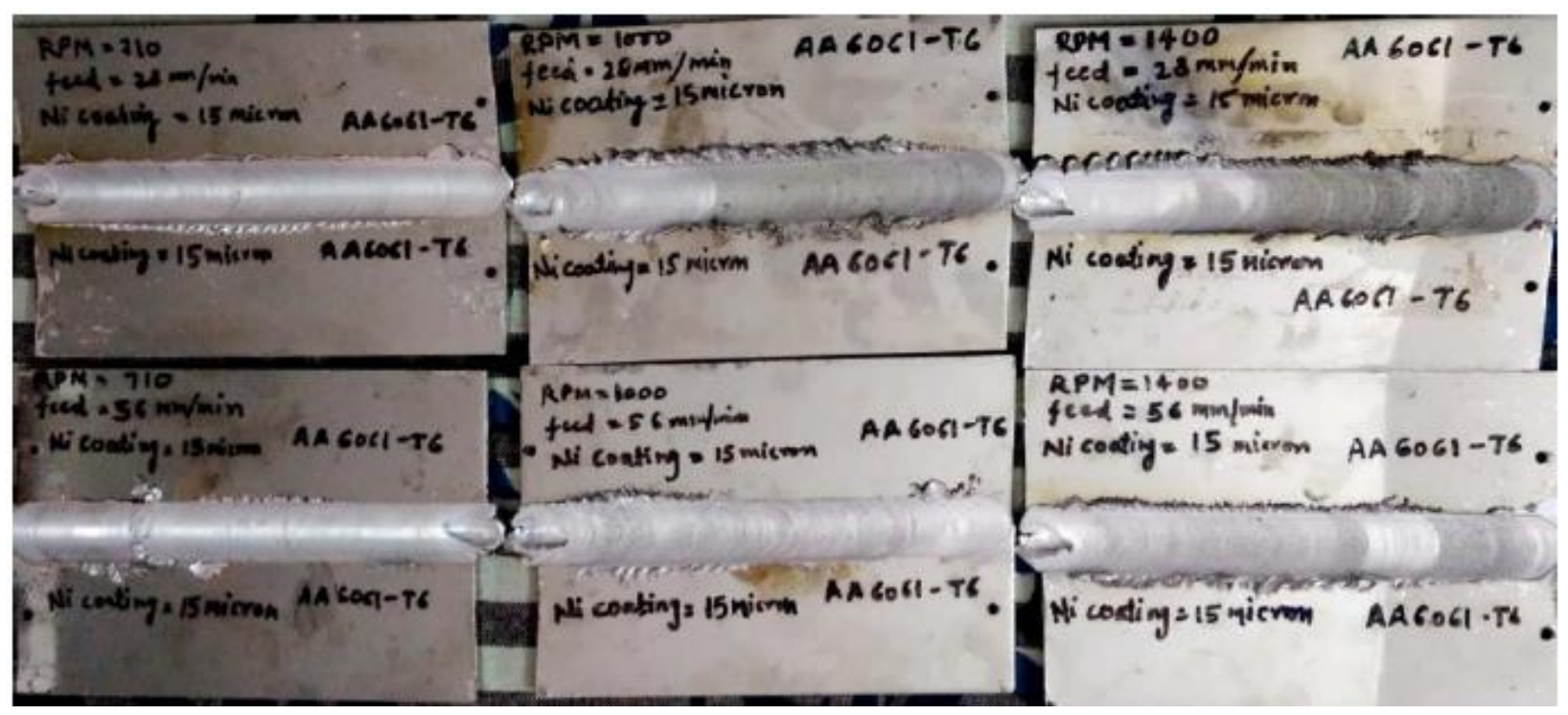

Fig. 2c FSW of 15micron thick Ni-coated AA6061-T6 plates

FSW was done on total eighteen samples with totally different welding speeds and rpm. Out of eighteen samples, six samples were of AA6061-T6 plates, six samples were of 10 micrometer thickness Ni coated AA6061-T6 plates and six samples were of 15 micrometer thickness Ni coated AA6061-T6 plates. Hence, a total 18 samples were friction stir welded using different tool rotation speed and different welding speed as shown in Figure 2a without coating, figure $2 \mathrm{~b}$ with $10 \mu \mathrm{m}$ nickel coating and figure $2 \mathrm{c}$ with $15 \mu \mathrm{m}$ nickel coating. The diameter of the shoulder for each tool was kept $18 \mathrm{~mm}$, as shown in Figure 3 and the welding process parameters are presented in Table 3. Figure 4 displays the fabricated FSW tool.

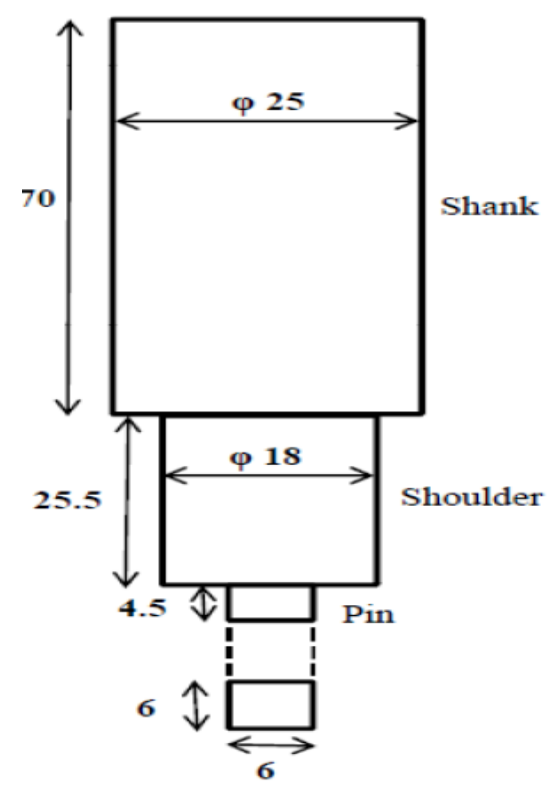

Fig. 3 Dimensions of tools

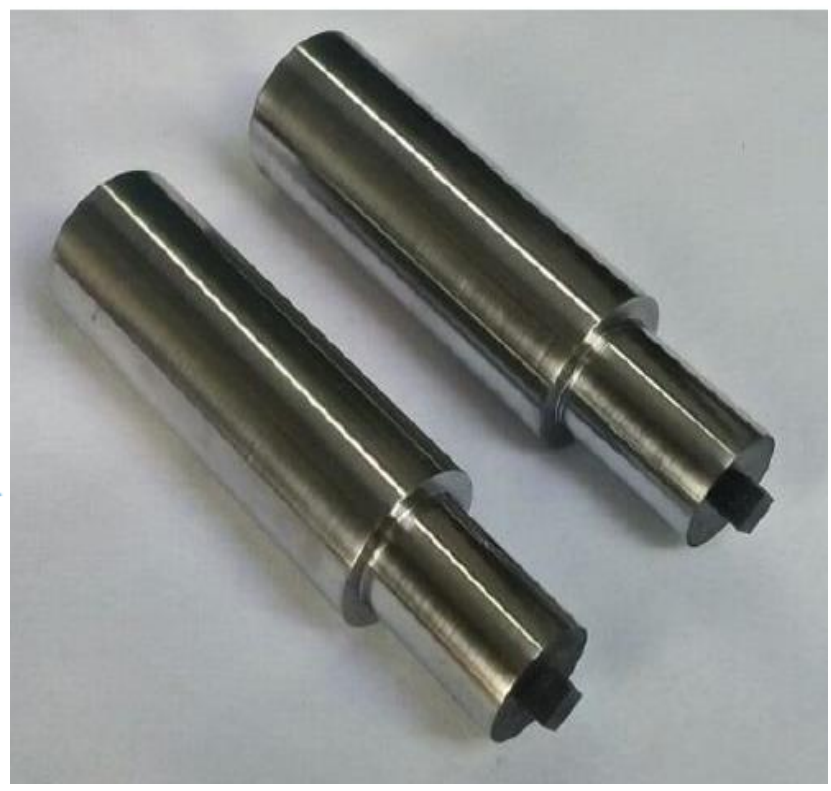

Fig. 4 H13 Tool steel for FSW of AA6061

After making ready FSW samples, the test specimen of appropriate dimensions' area unit was cut for various mechanical tests per ASTM standards. The tensile samples were prepared according to ASTM E-8 standard and their original and graphical view is represented by Figures 5(a) and (b) respectively. Vickers micro hardness test was carried out over the crosssection of FSW zones at different points. Vickers hardness testing machine with $5 \mathrm{~kg}$ applied load was employed for hardness measurement in present work. The setup impact testing machine determined the notch impact strength of the fabric by devastating the V-notched 
sample with a setup hammer, hard the impact strength. The quality sample sub size was $55 \times$ $10 \times 5$ metric linear unit and therefore the depth of the notch was $2 \mathrm{~mm}$, as per ISO 148. The size of the machine was taken as 1division equal to 2 joules. The prepared impact test specimen with $\mathrm{V}$ notch is presented in the figure 6.

Table 3: Welding parameters

\begin{tabular}{|l|l|}
\hline Process Parameters & Value \\
\hline Base Materials & AA6061, AA6061 with $10 \mu \mathrm{m}$ and $15 \mu \mathrm{m}$ Ni coating \\
\hline Tool Rotational Speed $(\mathrm{rpm})$ & $710,1000,1400$ \\
\hline Welding Speed $(\mathrm{mm} / \mathrm{min})$ & 28,56 \\
\hline Tool Shoulder Diameter $(\mathrm{mm})$ & 18 \\
\hline Tool Pin profile & Square \\
\hline Tool pin length and side $(\mathrm{mm})$ & 4.5 and 6 \\
\hline Tool material and tilt angle & H13 tool steel and $0^{\circ}$ \\
\hline
\end{tabular}

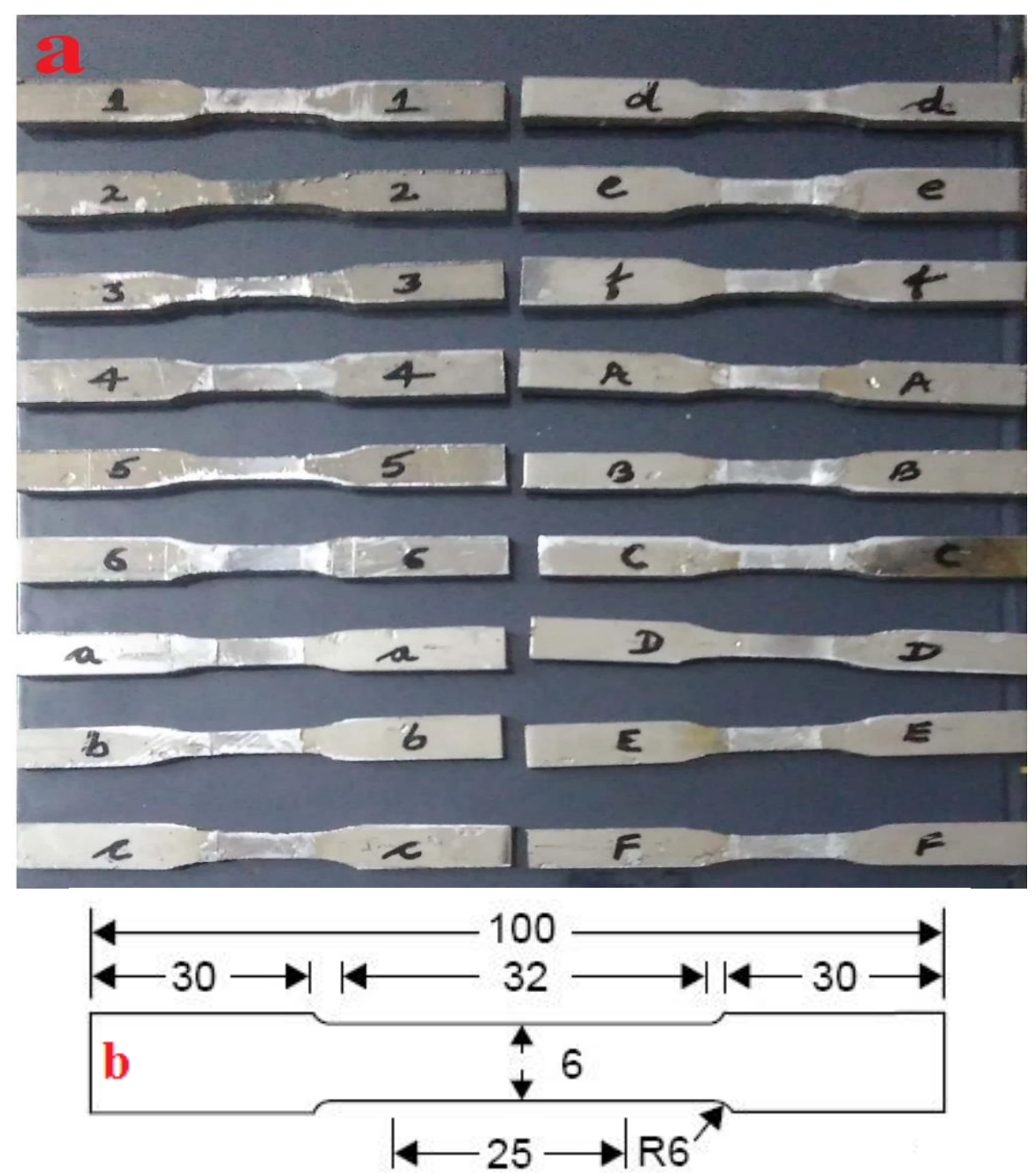

Fig. 5. (a) Tensile test samples (b) graphical view of tensile test sample.

The abrasion test of FSW specimens is performed on abrasion test rig (supplied by DUCOM) as per ASTM G65 standard. A total of 9 samples were designated out of eighteen samples for wear testing having maximum strength. FSW specimens of size $75 \mathrm{~mm} * 25 \mathrm{~mm}$ were prepared from the FSW zones for abrasion wear studies. The abrasive was fed at the contacting interface between the rotating rubber wheels and the specimen and the rate of feeding of the abrasive was maintained $365 \mathrm{~g} / \mathrm{min}$. A series of wear test was conducted by 
keeping constant parameters of Counter of 2000, $200 \mathrm{rpm}, 10 \mathrm{~N}$ Load and slippery distance of $630 \mathrm{~m}$. The graphical view of prepared sand abrasion wear sample before and after wear test as shown in Figures 7(a) and (b) respectively.

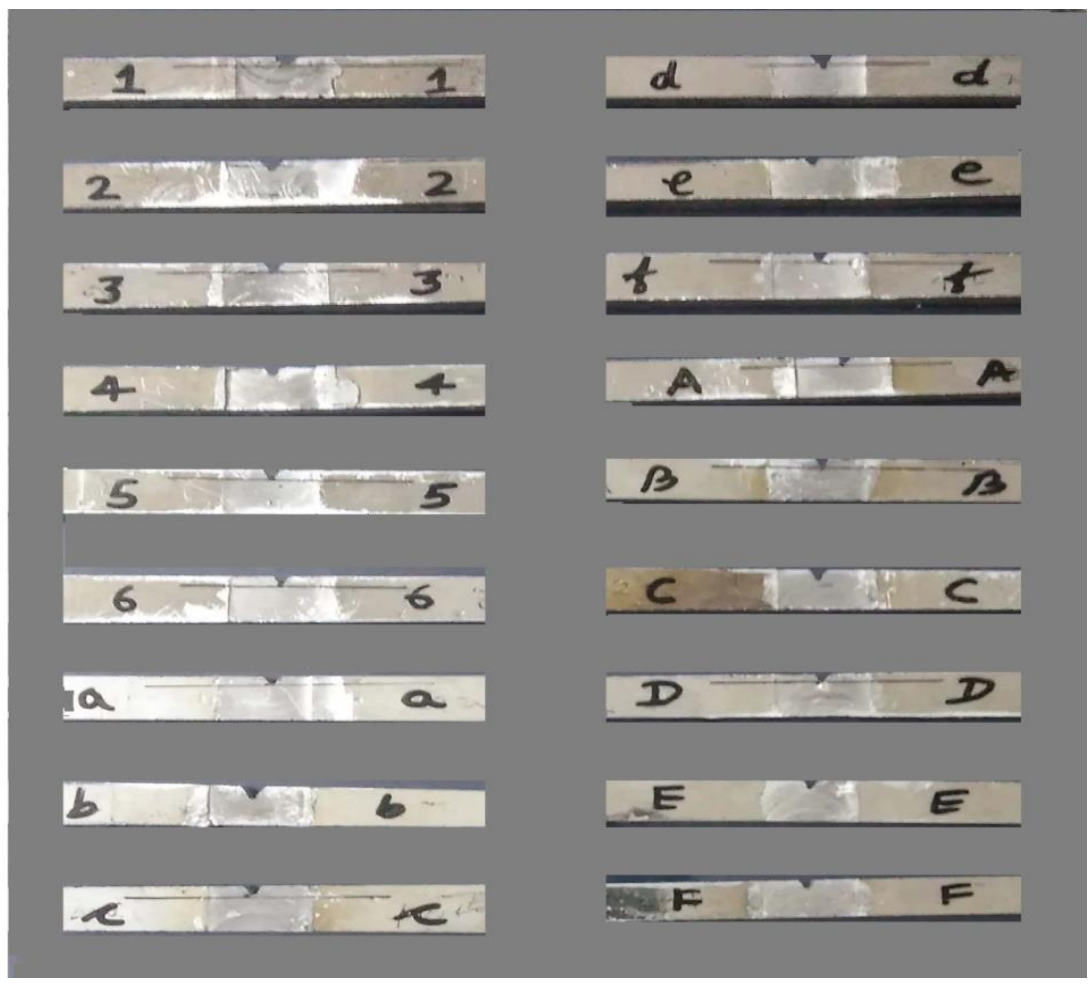

Fig. 6 Charpy test sample
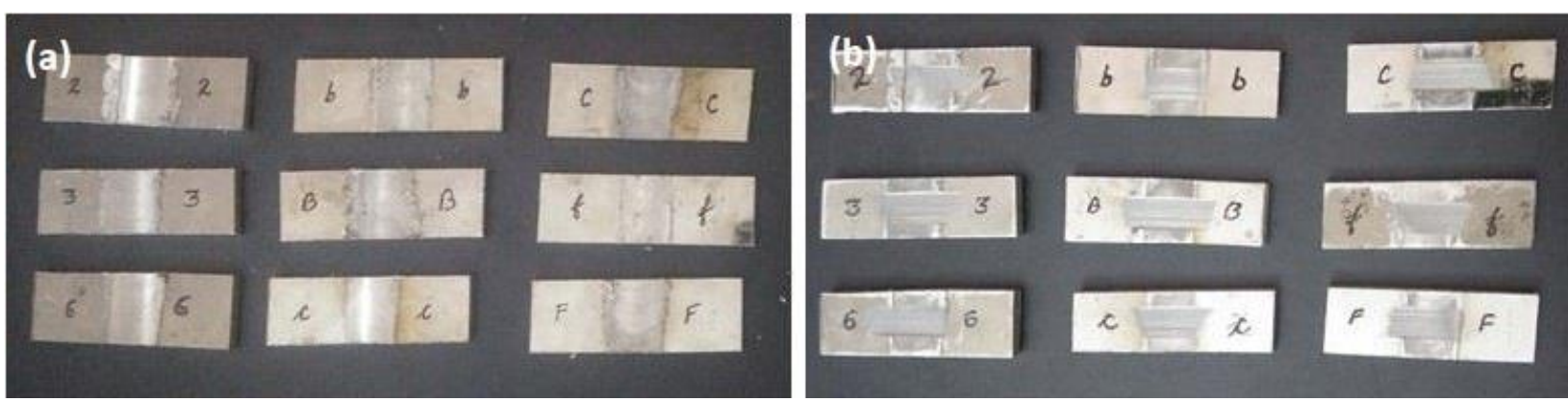

Fig. 7 Sand abrasion test samples (a) before wear (b) after wear

For evaluation of morphology of structure, microstructure examination was done on three samples. BANBROS created metallurgic magnifier with photographic camera connected to the computer was employed for microstructure observation. Microstructure was ascertained on the cross-sectional of welded samples. Firstly, sample's area unit was cut from welded plate and afterward finished by applying mineral papers of grit size 100, 320, 600, 1000, 2000. Finally, the samples were polished on single disc polishing machine by Hifinn diamond compound of grit size of $3 \mu \mathrm{m}$ and $1 \mu \mathrm{m}$ for 20 minutes and the etchant $(2 \mathrm{ml} \mathrm{HF}, 3 \mathrm{ml} \mathrm{HCL}$, $20 \mathrm{ml} \mathrm{HNO}_{3}$ and $175 \mathrm{ml}$ water) was employed for observing the microstructure and grain.

\section{Results and Discussion}

This section defines the mechanical properties (in terms of ultimate tensile strength, yield strength, \% elongation and hardness), Microstructural analysis and abrasive wear rate of friction stir welded AA6061-T6 Al alloy without and with nickel coating. 


\subsection{Ultimate Tensile Strength and \% Elongation}

The effect of tool rotation speed and welding speed on tensile strength, \% elongation and joint efficiency of FSW of aluminium alloy without (samples 1-2-3-4-5-6) and with $10 \mu \mathrm{m}$ (samples a-b-c-d-e-f) and $15 \mu \mathrm{m}$ (samples A-B-C-D-E-F) nickel coating is represented in table 4 and as shown in the figure 8 . Figure 8 shows that the joints produced using $1400 \mathrm{rpm}$ tool rotation speed and $56 \mathrm{~mm} / \mathrm{min}$ welding speed exhibits the highest tensile strength and \% elongation due to extreme plastic flow and proper mixing of aluminium alloys with nickel coating. The joint efficiency was evaluated by taking the percentage of the ratio of ultimate tensile strength of the welded joint to the ultimate tensile strength of the base metal. The ultimate tensile strength of the base aluminium alloy AA6061-T6 was taken as $308 \mathrm{MPa}$ as given in Table 2 .

Table 4: UTS, \% Elongation and Joint efficiency of FSW Sample

\begin{tabular}{|l|l|l|l|l|l|}
\hline $\begin{array}{l}\text { FSW } \\
\text { Samples }\end{array}$ & $\begin{array}{l}\text { Tool } \\
\text { RPM }\end{array}$ & $\begin{array}{l}\text { Welding } \\
\text { speed }\end{array}$ & UTS & $\begin{array}{l}\text { Elongation } \\
\text { at UTS }\end{array}$ & $\begin{array}{l}\text { Joint } \\
\text { efficiency (\%) }\end{array}$ \\
\hline 1 & 710 & 28 & 156.33 & 3.54 & 50.75 \\
\hline 2 & 1000 & 28 & 180.67 & 4.56 & 58.66 \\
\hline 3 & 1400 & 28 & 189.00 & 3.41 & 61.36 \\
\hline 4 & 710 & 56 & 154.00 & 3.09 & 50.00 \\
\hline 5 & 1000 & 56 & 177.33 & 3.54 & 57.57 \\
\hline 6 & 1400 & 56 & 195.00 & 3.63 & 63.31 \\
\hline a & 710 & 28 & 166.33 & 3.54 & 54.00 \\
\hline b & 1000 & 28 & 189.00 & 3.75 & 61.36 \\
\hline c & 1400 & 28 & 195.17 & 4.24 & 63.37 \\
\hline d & 710 & 56 & 161.33 & 3.75 & 52.38 \\
\hline e & 1000 & 56 & 171.67 & 3.39 & 55.74 \\
\hline f & 1400 & 56 & 195.33 & 4.24 & 63.42 \\
\hline A & 710 & 28 & 166.66 & 3.16 & 54.11 \\
\hline B & 1000 & 28 & 189.67 & 3.88 & 61.58 \\
\hline C & 1400 & 28 & 197.33 & 5.53 & 64.07 \\
\hline D & 710 & 56 & 166.66 & 3.16 & 54.11 \\
\hline E & 1000 & 56 & 171.67 & 3.94 & 55.74 \\
\hline F & 1400 & 56 & 212.67 & 6.18 & 69.05 \\
\hline
\end{tabular}

Figure 8 exhibits the stress-strain diagram of friction stress welded AA6061-T6 with and without $\mathrm{Ni}$ coating at different tool rotation speed and at welding speed of $28 \mathrm{~mm} / \mathrm{min}$. It can be observed from Figure 8 and Table 4 that the tensile strength of welded joint increases with increase in the tool rotation speed at constant welding speed of $28 \mathrm{~mm} / \mathrm{min}$. Further, the intermixing of the nickel coating in the stir zone imparts a better tensile strength to the welded joints than the welded joints without any coating. At 710 and $1000 \mathrm{rpm}$ tool rotation speed, the welded joints prepared after Ni coating of $10 \mu \mathrm{m}$ and $15 \mu \mathrm{m}$ of AA6061-T6 exhibit almost similar tensile properties, however at $1400 \mathrm{rpm}$, the FSW joints prepared with $15 \mu \mathrm{m} \mathrm{Ni}$ coating reveal better tensile strength than that of the FSW joints prepared from $10 \mu \mathrm{m} \mathrm{Ni}$ coating of AA6061-T6 aluminium alloy, which may be correlated to the improved intermixing of $\mathrm{Ni}$ in the stir zone at high TRS of $1400 \mathrm{rpm}$. 

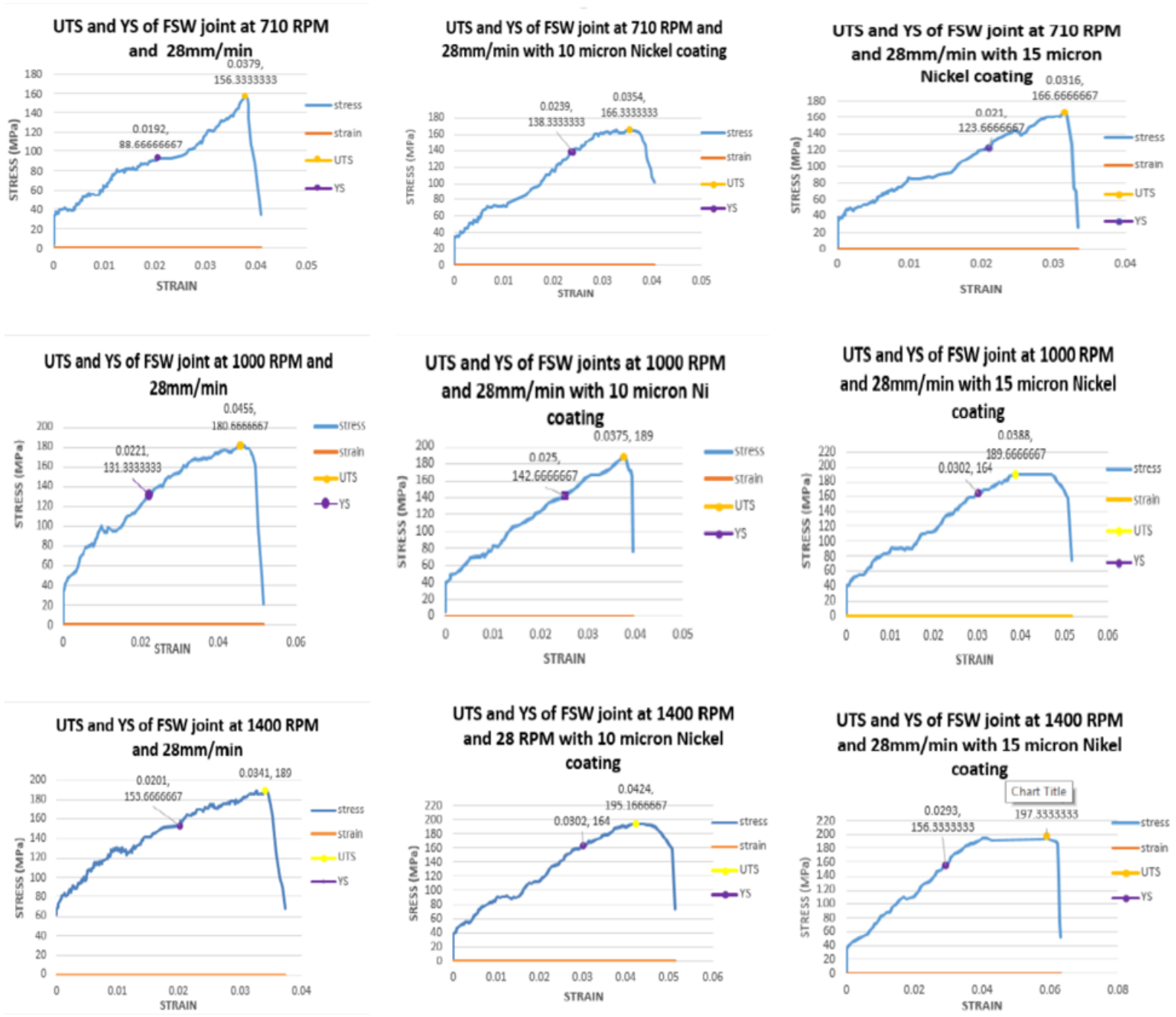

Fig. 8. The stress strain diagram for FSW sample

Figure 9 shows the stress strain diagram of FSW of AA6061-T6 with and without Ni coating at different tool rotation speed and fixed welding speed of $56 \mathrm{~mm} / \mathrm{min}$. The removal of defects in the nugget zone is the main reason for improving strength and \% elongation which may be caused by increasing the tool rotational speed thus improving the intermixing of nickel in the stir zone. After observing all the tensile data presented in Table 4, it can be concluded that the welded joints prepared at tool rotation speed of $1400 \mathrm{rpm}$ at either of 28 or $56 \mathrm{~mm} / \mathrm{min}$ welding speed exhibit better overall tensile properties with best tensile properties (Tensile strength $=212.67 \mathrm{MPa}$, elongation $=6.18 \%$ ) and joint efficiency of $69.05 \%$ shown by the sample coated with $15 \mu \mathrm{m}$ Ni coated AA6061-T6 aluminium alloy and welded at TRS of $1400 \mathrm{rpm}$ and welding speed of $56 \mathrm{~mm} / \mathrm{min}$. 

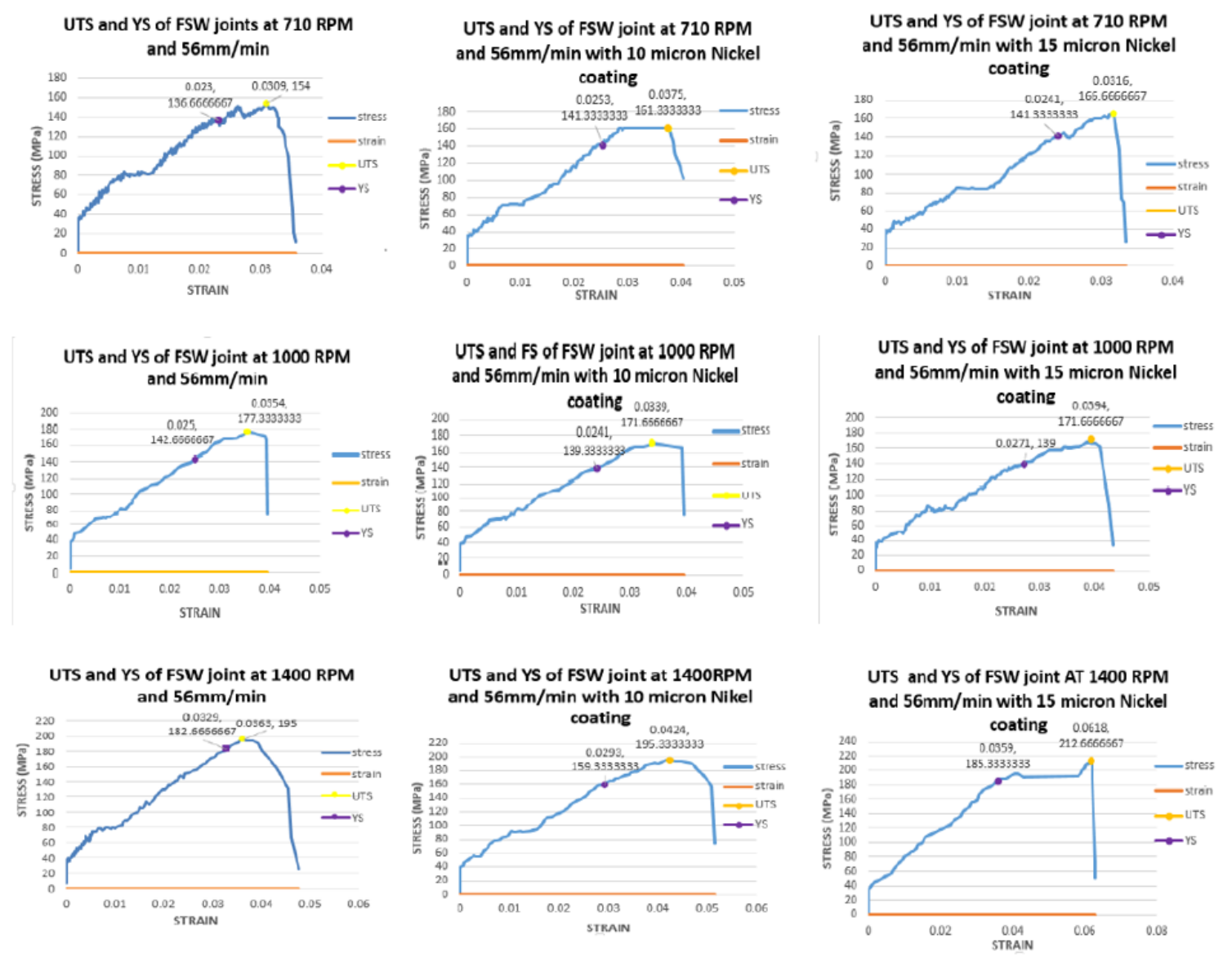

Fig. 9 The stress strain diagram for FSW sample

\subsection{Hardness Distribution}

Figures 10 demonstrates the microhardness profiles obtained from specific rotational speed of the tool and welding speed for all welded samples. There was much less variation between the hardness measurements taken along the top, middle, and bottom of each weld, therefore only the middle measurements were taken as shown in figures 10.

The overall shape of the microhardness profile is the characteristic showing letter $\mathrm{W}$ usually with and without Ni coating in AA6061-T6 friction stir welds. The hardness findings indicate that in most cases the hardness of samples with a coating thickness of 15 microns in the stir zone has a highest hardness value in the welded zone. 

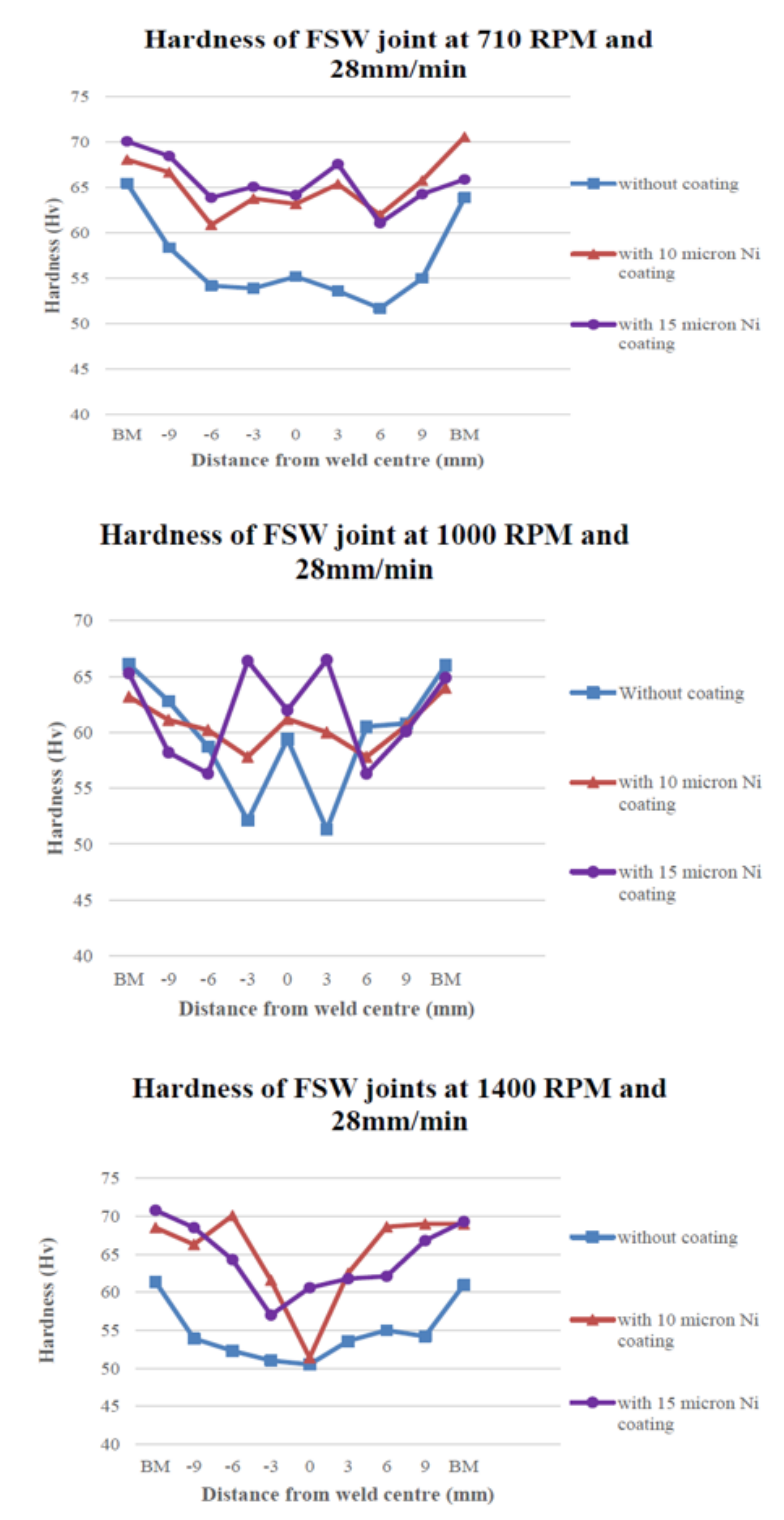
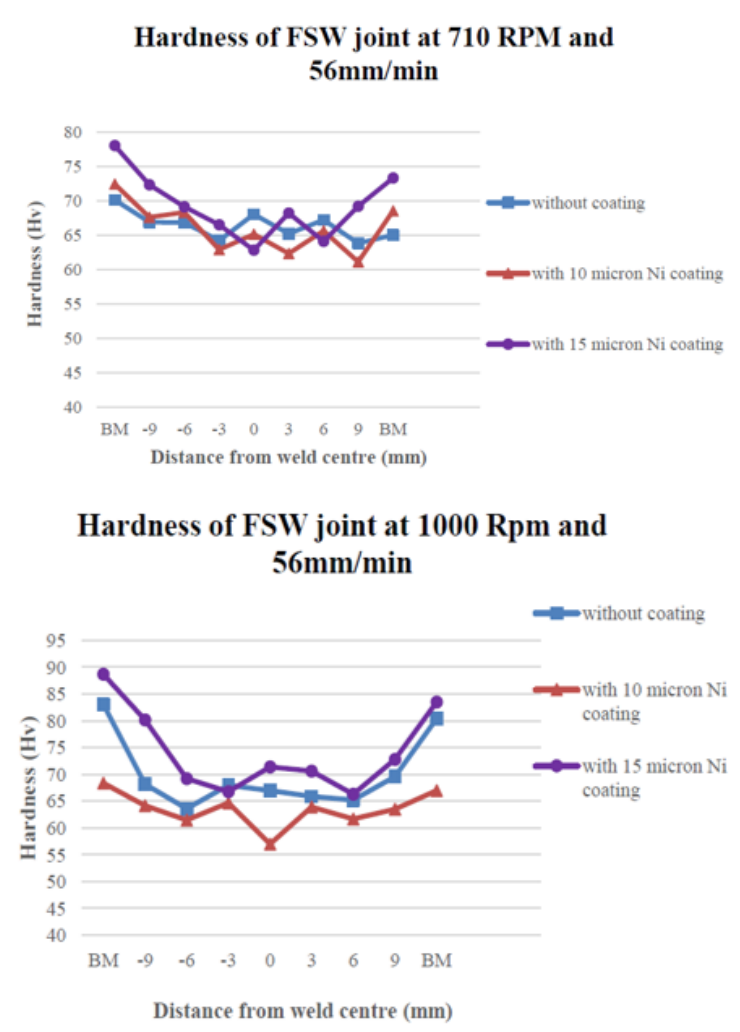

Hardness of FSW joint at 1400 RPM and $56 \mathrm{~mm} / \mathrm{min}$

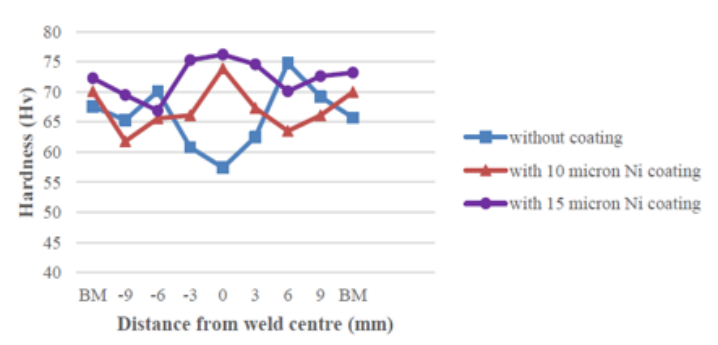

Fig. 10 The hardness distribution of FSW sample

\subsection{Impact Properties}

As shown in figure 11, the effect of tool rotation speed and welding speed on FSW aluminium alloy on impact energy without and with $10,15 \mu \mathrm{m}$ nickel coating is shown. Figure 11 shows that the joints produced using $1000 \mathrm{rpm}$ tool rotation speed and $28 \mathrm{~mm} / \mathrm{min}$ welding speed exhibits the highest impact energy due to proper mixing and lack of cracks in the aluminium alloys weld region. The joints formed using $710 \mathrm{rpm}$ tool rotation speed and 28 $\mathrm{mm} / \mathrm{min}$ welding speed result in less impact energy due to poor inter-mixing and plastic deformation as well as macroscopic deficiencies in the weld region. 


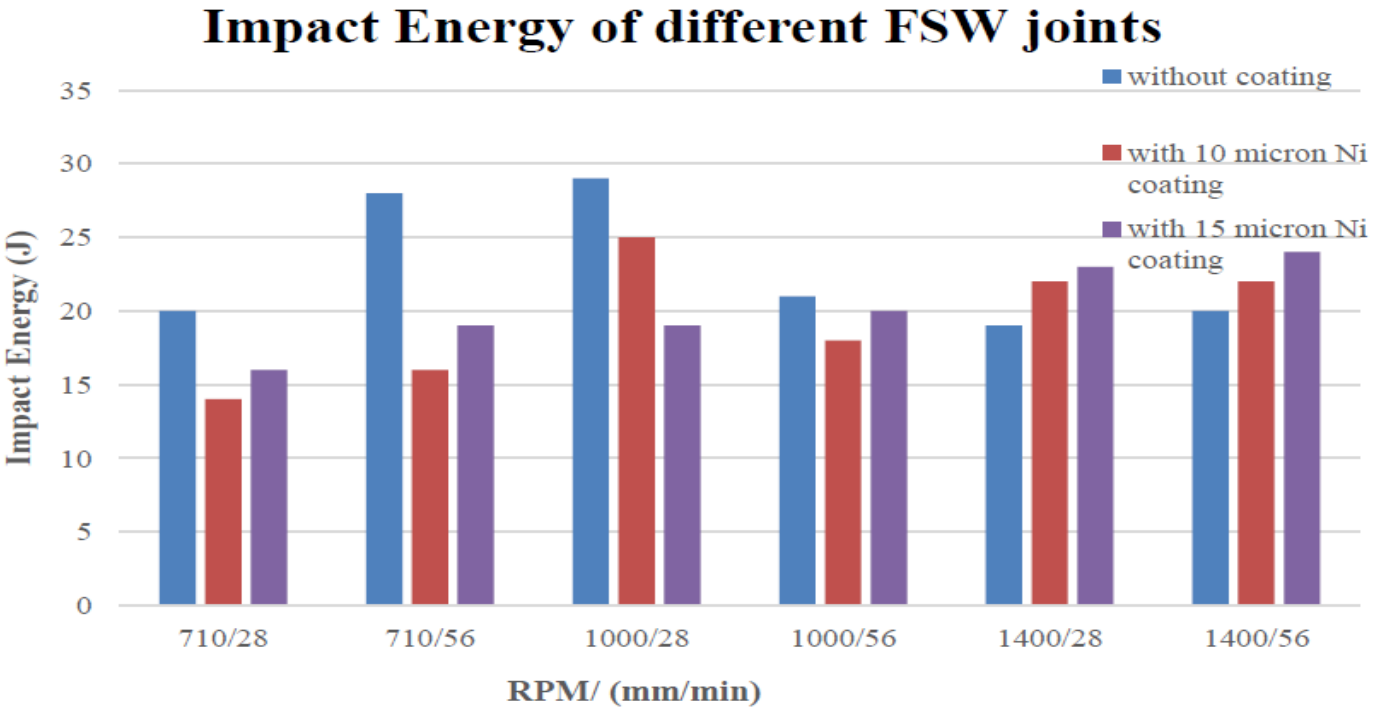

Fig. 11 The impact energy of FSW sample with and without Ni coating

\subsection{Microstructure Analysis}

Figure 12a, 12b, 12c displays the optical microstructure images captured from the stir region, HAZ and the base materials with and without nickel coating. There are clear changes visible in microstructures including fluctuations in precipitate size and its distribution after friction stir welding. The precipitates in the HAZ become slightly coarser, but finer in the nugget zone.
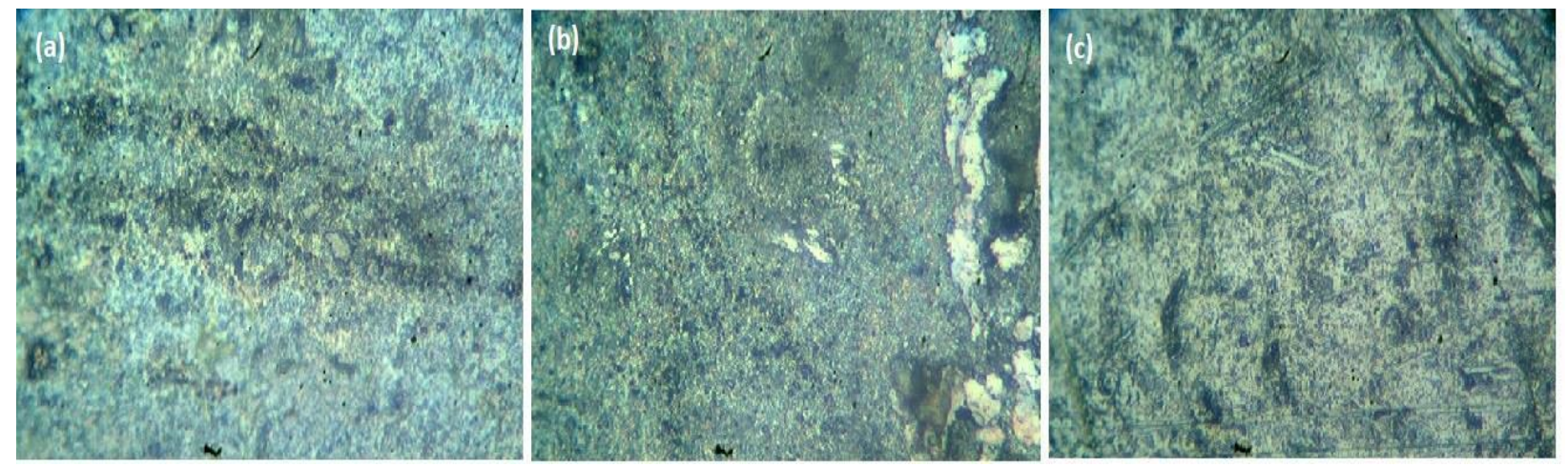

Fig. 12a Microstructure of FSW joint at 1400 RPM and $56 \mathrm{~mm} / \mathrm{min}$ without coating (a) stir zone (b) HAZ (c) base metal
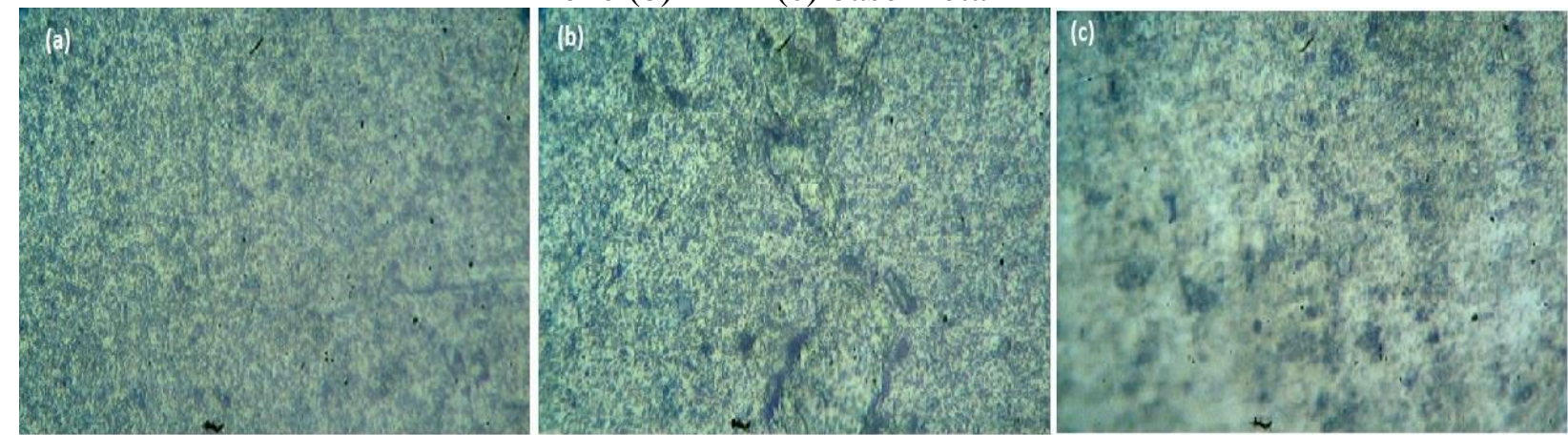

Fig. 12b Microstructure of FSW joint at 1400 RPM and $56 \mathrm{~mm} / \mathrm{min}$ with 10-micron Nickel coating (a) stir zone (b) HAZ (c) base metal 

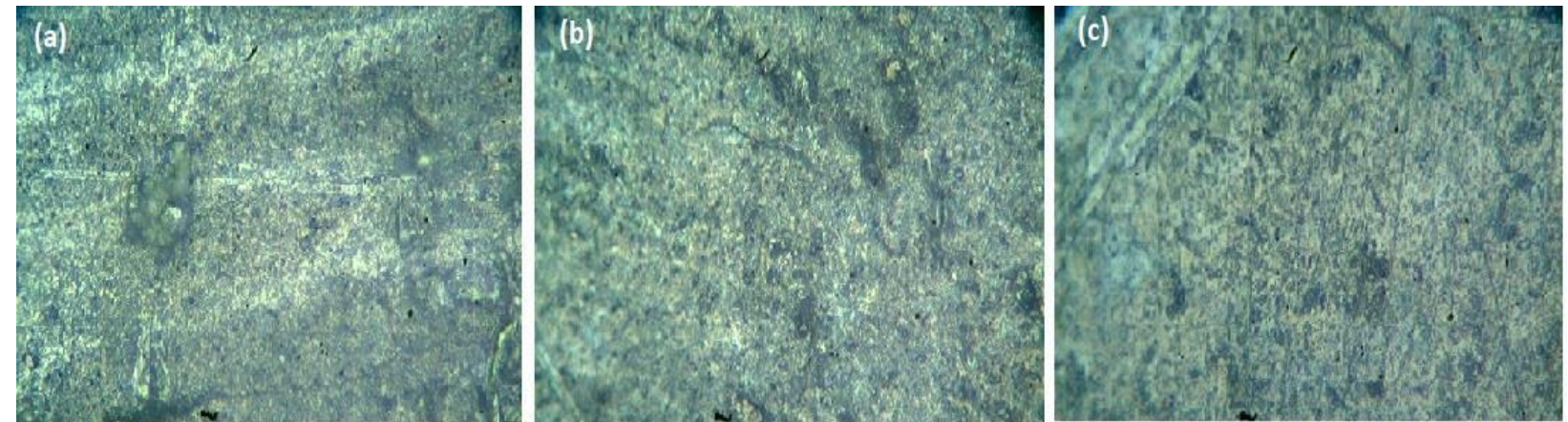

Fig. 12c Microstructure of FSW joint at 1400 RPM and $56 \mathrm{~mm} / \mathrm{min}$ with 15 -micron Nickel coating (a) stir zone (b) HAZ (c) base metal

\subsection{Sand Abrasion Wear Test}

The sand abrasive wear test results for 9 samples out of 18 samples at $365 \mathrm{gm} / \mathrm{min}$ rate of feeding of the abrasive are shown in Figure 13. Figure 13 shows that the joint produced from untreated aluminium alloy by FSW at $710 \mathrm{rpm}$ tool rotational speed and welding speed of 56 $\mathrm{mm} / \mathrm{min}$ possesses the best abrasive wear resistant properties. Among the 10 and $15 \mu \mathrm{m}$ nickel coated samples, at each tool rotation speed, the joints from $15 \mu \mathrm{m}$ nickel coated aluminium sheet shows better wear resistant properties that prepared from $10 \mu \mathrm{m}$ nickel coated samples. From figure 13, it is clear that the wear resistance properties decreases with the increase in tool rotation speed.

\section{Wear rate of different FSW joints}

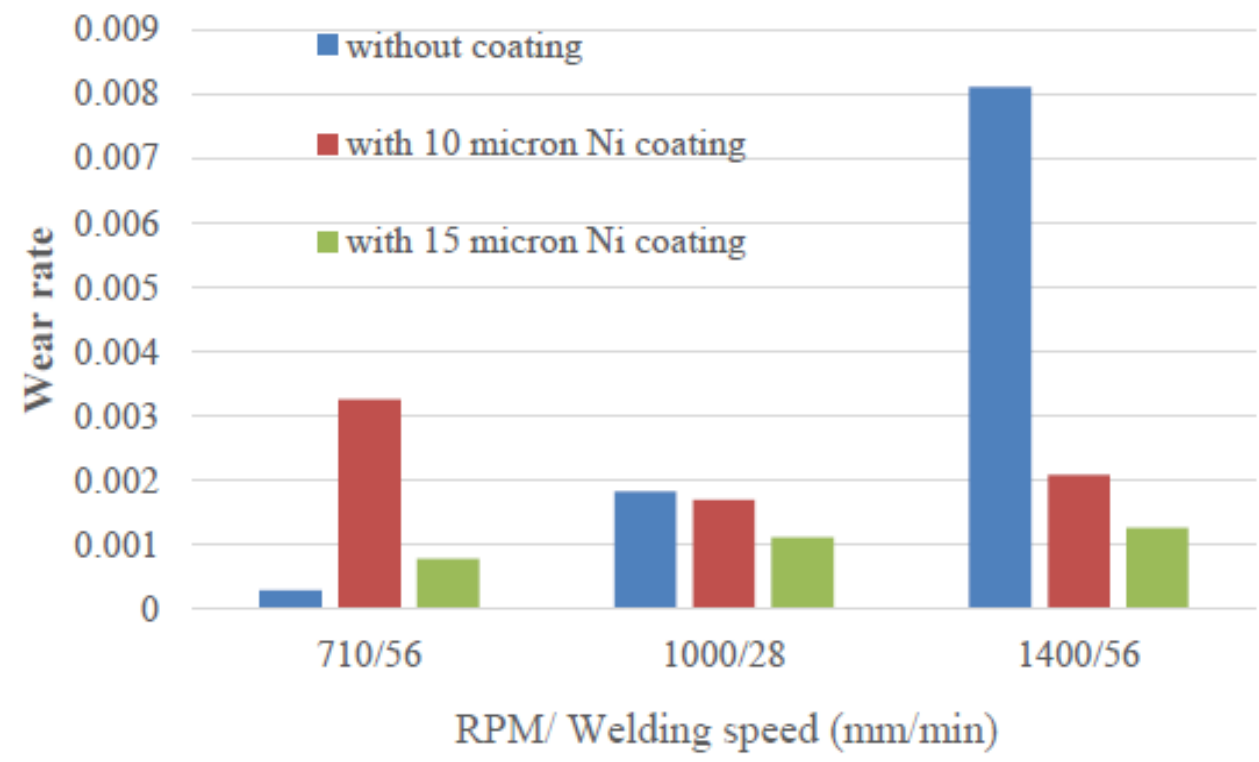

Fig. 13 Wear rate of different FSW Sample

\section{CONCLUSION}

The experimental study on the Effect of different welding speeds and tool rotation speeds on the mechanical and abrasive wear properties of friction stir welded AA6061-T6 Plates with/without Ni coating lead to the following conclusions: 
$>$ The nickel coating of AA6061-T6 aluminium alloy results in substantial improvement in tensile strength of FSW joints as compared to those FSW prepared without nickel coating at almost all combinations of welding speed and tool rotation speed. Also, the tensile strength of FSW joint of $15 \mu \mathrm{m}$ nickel coated AA6061-T6 plates is found to be more as compared to strength of FSW joint of $10 \mu \mathrm{m}$ nickel coated AA6061-T6 plates under same conditions of welding speed and tool rotation speed.

$>$ The optimized FSW parameter for all Ni-coated and uncoated AA6061-T6 aluminium alloy is achieved as tool rotation speed of $1400 \mathrm{rpm}$ and welding speed of $56 \mathrm{~mm} / \mathrm{min}$ at which the FSW joints of uncoated AA6061-T6, $10 \mu \mathrm{m}$ Ni-coated AA6061-T6 and $15 \mu \mathrm{m}$ Ni-coated AA6061-T6 aluminium ally exhibit the ultimate tensile strength of 195, 195.33 and 212.67 MPa respectively.

$>$ The greatest tensile strength $(212.67 \mathrm{MPa})$, percentage elongation $(6.18 \%)$ and joint efficiency $(69.05 \%)$ is demonstrated by the $15 \mu \mathrm{m} \mathrm{Ni}$-coated AA6061-T6 aluminium ally at $1400 \mathrm{rpm}$ TRS and $56 \mathrm{~mm} / \mathrm{min}$ welding speed.

$>$ The result of the hardness test shows that at $710 \mathrm{RPM}$ and $28 \mathrm{~mm} / \mathrm{min}$, the hardness of the Ni coated plates FSW joint are greater than the plates without coating, but at $56 \mathrm{~mm} / \mathrm{min}$ there is a minor variation in the hardness. At $1000 \mathrm{RPM}$, the hardness of the Ni-coated (15 micron) FSW joint improves near the weld center for both welding speeds (i.e. 28 $\mathrm{mm} / \mathrm{min}$ and $56 \mathrm{~mm} / \mathrm{min}$; better hardness with $15 \mu \mathrm{m} \mathrm{Ni-coated} \mathrm{sample)} \mathrm{as} \mathrm{compared} \mathrm{to}$ the FSW joint without coating. At 1400 RPM, the hardness of the FSW joint of Ni coated plates is increased when welded at a welding speed of $28 \mathrm{~mm} / \mathrm{min}$ compared to the plates without coating, but at a welding speed of $56 \mathrm{~mm} / \mathrm{min}$, the hardness of the FSW joint of $\mathrm{Ni}$ coated plates is only increased near the welding center. Therefore, the welding parameters i.e. $1400 \mathrm{RPM}$ and $28 \mathrm{~mm} / \mathrm{min}$ imparts better hardness to the nickel-coated FSW joint AA6061-T6 Plates. Hardness also depends directly on the thickness of the coating.

$>$ Charpy test result shows that at 710 RPM and 1000 RPM for both welding speed (i.e. 28 $\mathrm{mm} / \mathrm{min} \& 56 \mathrm{~mm} / \mathrm{min}$ ), there is a decrement in impact properties of FSW joint of $\mathrm{Ni}$ coated AA6061-T6 Plates as compared to the plates without coating. However, at 1400 RPM, impact properties of FSW joint of Ni coated AA6061-T6 plates get better as compared to the plates (without coating) for both welding speed of 28 and $56 \mathrm{~mm} / \mathrm{min}$. Hence, for better impact properties of the FSW joint of Ni coated AA6061-T6 plates, higher tool rotation speed (i.e. 1400 RPM) should be preferred. Also, at this tool rotation speed, impact properties increase as the thickness of the coating increases. Among the Nicoated samples, the best impact strength of 25 Joule is revealed by the sample with $10 \mu \mathrm{m}$ $\mathrm{Ni}$ coating and welded at TRS of $1000 \mathrm{RPM}$ and welding speed of $28 \mathrm{~mm} / \mathrm{min}$. The joint possessing greatest tensile properties (i.e. FSW joint made at $1400 \mathrm{rpm}$ and $56 \mathrm{~mm} / \mathrm{min}$ of $15 \mu \mathrm{m}$ Ni-coated AA6061-T6) exhibits also a very good impact strength of 24 Joule.

$>$ In Microstructure Analysis, it is revealed that the grain refinement is better in the stir zone than HAZ and base metal. As the thickness of the coating increases the size of the grains decreases. Samples with $1400 \mathrm{RPM}$ and $56 \mathrm{~mm} / \mathrm{min}$ demonstrate maximum tensile strength due to the fine grain size. The order of average grain size for various weld zones was as follows: base metal $(\mathrm{BM})>$ heat affected zone (HAZ) > stir zone (SZ).

$>$ Sand abrasion wear test results shows that at $710 \mathrm{RPM}$ and $56 \mathrm{~mm} / \mathrm{min}$, Ni coating imposes a negative effect on the wear properties of FSW joints as compared to the plates without coating. However, at $1000 \mathrm{rpm}$ and $28 \mathrm{~mm} / \mathrm{min}$ as well as at $1400 \mathrm{RPM}$ and 56 $\mathrm{mm} / \mathrm{min}$ parameters, the wear rate of FSW joint of Ni coated AA6061-T6 plates is significantly decreased as compared to the plates without coating. Thus, for better wear properties of the FSW joint of Ni coated AA6061-T6 Plates, higher tool rotation speed 
(i.e. 1400 RPM) should be preferred. Also, at this tool rotation speed, wear rate decreases as the thickness of the coating increases.

\section{REFERENCES}

[1] Patel, V. K., Bhowmik, S. "Plasma processing of aluminum alloy to promote adhesionA critical review", Reviews of Adhesion and Adhesives 5, pp. 79 - 104, 2017.

[2] Bisht, A., Gangil, B., Patel, V. K. "Selection of blowing agent for metal foam production: A review", Journal of Metals, Materials and Minerals 30 (1), pp. 1 - 10, 2020.

[3] Bisht, A., Patel, V. K., Gangil, B. "Future of metal foam materials in automotive industry”, In Automotive Tribology, Springer Singapore, pp. 51 - 63, 2019.

[4] http://www.aluminum.matter.org.uk/content/html/eng/default.asp?catid=49

[5] Mathers, G. “The welding of aluminum and its alloys", Woodhead Publishing, p. 248, 2002.

[6] Patel, V. K., Kumar, P., Bhattacharya, S. "Mechanical microstructural and sliding wear properties of friction stir welded AA6063-T6 and AA5052-H32 aluminum alloys", Materials Focus 7, pp. 50 - 58, 2018.

[7] Colligan, K. J. "Frictions stir welding for ship construction", Concurrent Technologies Corporation, Harrisburg, PA, 2004.

[8] The Welding Institute TWI. www.twi.co.uk.

[9] Dawes, C., Thomas, W. "Friction stir joining of aluminium alloys", TWI Bulletin 6, pp. $124,1995$.

[10] Patel, V. K., Rani, K. "Mechanical and wear properties of friction stir welded 0-6Wt\% $\mathrm{nAl}_{2} \mathrm{O}_{3}$ reinforced $\mathrm{Al}-13 \mathrm{Wt} \% \mathrm{Si}$ composites", Strojnícky časopis - Journal of Mechanical Engineering 67 (1), pp. 77 - 86, 2017. DOI: 10.1515/scjme-2017-0008

[11] Mishra, R. S., Ma, Z. Y. "Friction stir welding and processing", Materials Science and Engineering: R: Reports 50, pp. 1 - 78, 2005.

[12] Thomas, W. M., Johnson, K. I., Wiesner, C. S. "Friction stir welding-recent developments in tool and process technologies", Advanced Engineering Materials 5, pp. $485-490,2003$.

[13] Handa A, Chawla V. "Experimental evaluation of mechanical properties of friction welded dissimilar steels under varying axial pressures", Strojnícky časopis - Journal of Mechanical Engineering 66 (1), pp. 27 - 36, 2016. DOI: 10.1515/scjme-2016-0008

[14] Arya, P. K., Gupta, G., Rajput, A. K. "A Review on friction stir welding for aluminium alloy to steel", International Journal of Scientific \& Engineering Research 7 (5), 119, 2016.

[15] Meilinger, Á., Török, I. "The importance of friction stir welding tool", Production Processes and Systems 6, pp. 25 - 34, 2013.

[16] Jančo, R, Écsi, L, Élesztős, P. "FSW Numerical simulation of aluminium plates by sysweld-Part II”. Strojnícky časopis - Journal of Mechanical Engineering 66 (2), pp. 29 - 36, 2016. DOI: $10.1515 /$ scjme-2016-0016 
[17] Kumar, N., Patel, V. K. "Effect of $\mathrm{SiC} / \mathrm{Si}_{3} \mathrm{~N}_{4}$ micro-reinforcement on mechanical and wear properties of friction stir welded AA6061-T6 aluminum alloy", SN Applied Sciences 2, pp. 1572, 2020.

[18] Cavaliere, P., Squillace, A., Panella, F. "Effect of welding parameters on mechanical and microstructural properties of AA6082 joints produced by FSW", Journal of Materials Processing Technology 200, pp. 364 - 372, 2008.

[19] Xu, W., Liu, J., Luan, G., Dong, C. "Temperature evolution, Micro-structure and Mechanical properties of friction stir welded thick 2219-O Al Alloy joints", Materials and Design 30, pp. 1886 - 1893, 2009.

[20] Rodrigues, D. M., Loureiro, A., Leitao, C., Leal, R. M., Chaparro, B. M., Vilaça, P. "Influence of friction stir welding parameters on the microstructural and mechanical properties of AA 6016-T4 thin welds", Materials and Design 30, pp. 1913 - 1921, 2009.

[21] Cavaliere, P., Campanile, G., Panella, F., Squillace, A. "Effect of welding parameters on mechanical and microstructural properties of AA6056 joints produced by FSW" Journal of Materials Processing Technology 180, pp. 263 - 270, 2006.

[22] Sharma, C., Dwivedi, D. K., Kumar, P. "Effect of welding parameters on microstructural and mechanical properties of FSW joints of AA7039 Al Alloy", Materials and Design 36, pp. 379 - 390, 2012.

[23] Fujii, H., Cui, L., Masakatsu, M., Nogi, K. "Effect of tool shape on mechanical properties and microstructure of friction stir welded Al Alloys", Materials Science and Engineering A 419, pp. 25 - 31, 2006.

[24] Scialpi, A., Filippis, L. A .C. D., Cavaliere, P. "Influence of shoulder geometry on microstructure and mechanical properties of friction stir welded 6082 aluminium alloy", Materials and Design 28, pp. 1124 - 1129, 2007.

[25] Elangovan, K., Balasubramanian, V., Babu, S. "Predicting tensile strength of friction stir welded AA6061 aluminium alloy joints by a mathematical model", Materials and Design 30, pp. 188 - 193, 2009.

[26] Kumar, K., Kailas, S. V. "On the role of axial load and the effect of interface position on the tensile strength of a friction stir welded aluminium alloy", Materials and Design 29, pp. $791-797,2008$.

[27] Dehghani, K., Ghorbani, R., Soltanipoor, A. R. "Microstructural evolution and mechanical properties during the friction stir welding of 7075-O aluminum alloy", The International Journal of Advanced Manufacturing Technology 77, pp. 1671 - 1679, 2015. 